\title{
ACUTE METABOLIC ALKALOSIS: ITS EFFECT ON POTASSIUM AND ACID EXCRETION ${ }^{1}$
}

\author{
By MALCOLM A. HOLLIDAY with THE technical ASSistance of ARLENE LUKEN- \\ BILL AND CHARLES HANCOCK
}

(From the Department of Pediatrics, Indiana University Medical Center, Indianapolis, Ind.)

(Submitted for publication February 15, 1954; accepted November 10, 1954)

Potassium secretion was first described in 1949 $(1,2)$ in response to large infusions of potassium chloride. Later, Berliner, Kennedy, and Orloff (3) demonstrated an inverse relationship between potassium excretion and acid excretion defined as the sum of ammonia and titratable acid. More recently, Berliner (4) suggested that hydrogen secretion effects the reabsorption of sodium, and the latter would serve as an approximate definition of acid excretion.

The present study is a report of the urinary excretion of electrolyte in response to metabolic alkalosis induced by the removal of chloride. This circumstance is known to lead to potassium deficiency (5) and presumably potassium excretion. By providing various loads of electrolyte subsequent to the induction of alkalosis, the relation of ammonia and titratable acid excretion to potassium excretion was observed under a variety of circumstances which had in common an increased excretion of potassium.

\section{METHODS}

Male albino rats weighing 275 to $325 \mathrm{gm}$. were used in the experiment. In order to obtain urine excretion values for sodium, potassium, and chloride which would be minimally affected .by food intake, a diet deficient in these ions and also low in phosphate was used.2 The experiments were run for a total of six days.

1 The work was conducted under a grant from the James Whitcomb Riley Memorial Association.

2 The composition of the low electrolyte diet was as follows :

Casein 21 per cent

Corn Oil 20 per cent

Sucrose 15 per cent

Salt Mixture 1.6 per cent

$\mathrm{CaCO}_{8}-1.0$ per cent

$\mathrm{FeSO}_{4}-.08$ per cent

$\mathrm{MgSO} 7 \mathrm{H}_{2} \mathrm{O}-.45$ per cent

$\mathrm{MnSO}_{4}-.023$ per cent

Synthetic vitamins were added as recommended by Riggs, T. R., and Hegsted, D. M. (J. Biol. Chem., 1949, 178, 669). Urea was used to increase the otherwise low osmolar load and thereby increase urine flow.
All animals were permitted to adjust to the diet for the first three days. Urine excretion of sodium, potassium, and chloride was negligible after two days on the diet, and excretion values for the third day were used as controls for those of subsequent days. At the end of the three-day adjustment period the animals were divided into five groups (I-V). Animals in each group were subjected to the intraperitoneal injection of $10 \mathrm{ml}$. fluid per $100 \mathrm{gm}$. body weight of the composition indicated in Table I. The injected fluid was permitted to equilibrate with extracellular fluid for two hours (6) and was then removed. The volume removed closely approximated the volume injected. The average composition of the fluid removed and the net loss of chloride effected by the procedure are given in Table I.

Group I was injected with a solution which approximated extracellular fluid in composition so that upon removal minimal balances were effected. This group served as controls for the subsequent groups.

Group II was injected with isotonic sodium bicarbonate. The bicarbonate exchanged for chloride, resulting in a net loss of chloride.

Group III was injected with a hypertonic solution of sodium bicarbonate so that not only did chloride exchange for bicarbonate producing chloride depletion, but sodium bicarbonate was also absorbed. In addition, $2.0 \mathrm{mM}$ of sodium bicarbonate was given on day 5 and day 6 of the experiment in the drinking water.

Group IV was injected with a solution of sodium bicarbonate containing, in addition, sodium phosphate. This resulted in chloride depletion with a gain of sodium phosphate. Two mM of sodium phosphate was also given in the drinking water on day 5 and day 6.

Group V was injected with isotonic sodium nitrate solution so that nitrate, rather than bicarbonate, would exchange for chloride to provide a fixed anion substitute for chloride. No load was given.

Urine, preserved with thymol, was collected under mineral oil in twenty-four-hour periods on the third day which preceded lavage, and on the fourth, fifth and sixth days following lavage.

At the end of the sixth day the animals were sacrificed by exsanguination from the abdominal aorta. Serum and muscle were obtained for analysis. The viscera were fixed in formalin for histological examination.

Sodium and potassium determinations were done by internal standard flame photometry (7); phosphorus determinations by the method of Fiske and SubbaRow (8). Serum and peritoneal fluid chlorides were done by Van Slyke and Hiller's modification of the iodometric 
TABLE I

Data on peritoneal lavage*

\begin{tabular}{|c|c|c|c|c|c|c|c|c|c|c|c|}
\hline \multirow{2}{*}{$\begin{array}{l}\text { Experi- } \\
\text { mental } \\
\text { groups }\end{array}$} & \multirow[b]{2}{*}{$\begin{array}{l}\text { No. } \\
\text { rats }\end{array}$} & \multicolumn{5}{|c|}{ Composition of fluid injected $\dagger$} & \multicolumn{4}{|c|}{ Composition of fluid removed } & \multirow{2}{*}{$\begin{array}{c}\text { Chloride } \\
\text { balance } \\
m M\end{array}$} \\
\hline & & $\underset{m M / L}{\mathrm{Na}}$ & $\underset{m M / L}{\mathrm{Cl}}$ & $\underset{m M / L}{\mathrm{CO}_{2}}$ & ${ }_{m M / L}$ & $\underset{m M / L}{N O_{3}}$ & $\stackrel{\mathrm{Na}}{m M / L}$ & $\underset{m M / L}{\mathrm{Cl}}$ & ${ }_{m M / L}^{C_{2}}$ & $\underset{m M / L}{\mathbf{K}}$ & \\
\hline $\begin{array}{l}\text { I } \\
\text { II } \\
\text { III } \\
\text { IV } \\
\text { V }\end{array}$ & $\begin{array}{l}8 \\
7 \\
6 \\
6 \\
6\end{array}$ & $\begin{array}{l}145 \\
150 \\
200 \\
200 \\
150\end{array}$ & $\begin{array}{r}115 \\
0 \\
0 \\
0\end{array}$ & $\begin{array}{c}30 \\
150 \\
200 \\
100 t \\
0\end{array}$ & $\begin{array}{c}0 \\
0 \\
0 \\
50 \neq \\
0\end{array}$ & $\begin{array}{r}0 \\
0 \\
0 \\
0 \\
150\end{array}$ & $\begin{array}{l}133.7 \\
136.7 \\
142.1 \\
146.9 \\
132.7\end{array}$ & $\begin{array}{r}105.4 \\
75.3 \\
76.6 \\
77.8 \\
75.8\end{array}$ & $\begin{array}{l}29.7 \\
54.2 \\
62.8 \\
47.6 \\
22.0\end{array}$ & $\begin{array}{l}3.7 \\
3.3 \\
2.8 \\
3.1 \\
2.4\end{array}$ & $\begin{array}{l}+0.3 \\
-2.2 \\
-2.0 \\
-2.2 \\
-2.3\end{array}$ \\
\hline
\end{tabular}

* Averages for each group.

† Fluid contained 2 per cent glucose to prevent absorption. The volume injected was equal to 10 per cent of body weight of the animal, and the volume removed was very nearly equal to the volume injected.

$\ddagger$ One hundred mEq. of $\mathrm{HCO}_{3}^{-}+\mathrm{HPO}_{4}$ - estimated from adding $50 \mathrm{mM}$ sodium acid phosphate to $150 \mathrm{mM} \mathrm{NaHCO}$.

method of Sendroy (9), carbon dioxide content by the method of Van Slyke and Neill (10), urine $\mathrm{pH}$ and titratable acid were determined on a Beckman Model G $\mathrm{pH}$ meter with an electrometric titration assembly, urine ammonia and all nitrate analyses were done by the diffusion method of Conway (11), and urine and tissue chloride by the Volhard titration (12). The water content of the muscle was obtained by difference in weights before and after drying at 100 to $110^{\circ} \mathrm{C}$. for three days. The dry muscle was then ground, redried and aliquots freed of fat by three extractions with equal parts of petroleum and ethyl ether. The dried fat free residue was then extracted with $0.75 \mathrm{~N}$ nitric acid for two days and aliquots of this taken for sodium, potassium, and chloride analyses by methods referred to previously.

\section{RESULTS}

Detailed data for the urinary excretion of electrolyte on the day preceding lavage and for the three days after lavage are presented in Table II.

In Figure 1, potassium excretion, acid excretion, urine $\mathrm{pH}$, and total anion excretion are represented graphically. Acid excretion is expressed as the sum of ammonia and titratable acid. Total

TABLE II

Average values for urine excretion of electrolytes *

\begin{tabular}{|c|c|c|c|c|c|c|c|c|c|c|c|c|}
\hline Experimental groups & Day & $\begin{array}{l}\text { Electrolyte } \\
\text { intake }\end{array}$ & $\mathbf{N a}$ & $\mathbf{K}$ & $\mathrm{NH}_{4}$ & T.A. & $\mathrm{NH}_{4}+\mathrm{TA}$ & $\mathrm{pH}$ & PO، & $\mathrm{NO}_{3}$ & $\mathbf{C l}$ & $\underset{\mathbf{N H}+\mathrm{T} . \mathbf{A} .}{\mathrm{Na}}$ \\
\hline $\begin{array}{l}\text { All groups-prior to } \\
\text { lavage "control day" }\end{array}$ & 3 & 0 & .07 & .06 & 1.07 & .09 & 1.16 & 6.9 & .15 & - & .17 & 1.29 \\
\hline I. Control lavage & $\begin{array}{l}4 \\
5 \\
6\end{array}$ & $\begin{array}{l}\mathbf{0} \\
\mathbf{0} \\
\mathbf{0}\end{array}$ & $\begin{array}{l}.22 \\
.11 \\
.05\end{array}$ & $\begin{array}{l}.08 \\
.04 \\
.04\end{array}$ & $\begin{array}{l}1.35 \\
1.13 \\
1.16\end{array}$ & $\begin{array}{l}.16 \\
.22 \\
.03\end{array}$ & $\begin{array}{l}1.51 \\
1.35 \\
1.19\end{array}$ & $\begin{array}{l}6.6 \\
6.8 \\
7.3\end{array}$ & $\begin{array}{l}.33 \\
.09 \\
.05\end{array}$ & - & $\begin{array}{l}.39 \\
.18 \\
.18\end{array}$ & $\begin{array}{l}1.81 \\
1.50 \\
1.28\end{array}$ \\
\hline $\begin{array}{l}\text { II. Chloride depleted } \\
\text { using bicarbonate }\end{array}$ & $\begin{array}{l}4 \\
5 \\
6\end{array}$ & $\begin{array}{l}0 \\
0 \\
0\end{array}$ & $\begin{array}{r}1.02 \\
.15 \\
.08\end{array}$ & $\begin{array}{l}.73 \\
.83 \\
.41\end{array}$ & $\begin{array}{l}.42 \\
.49 \\
.80\end{array}$ & $\begin{array}{l}.16 \\
.30 \\
.41\end{array}$ & $\begin{array}{r}.58 \\
.79 \\
1.21\end{array}$ & $\begin{array}{l}6.8 \\
6.1 \\
6.3\end{array}$ & $\begin{array}{r}.64 \\
.35 \\
.29\end{array}$ & - & $\begin{array}{l}.15 \\
.04 \\
.04\end{array}$ & $\begin{array}{l}2.33 \\
1.77 \\
1.70\end{array}$ \\
\hline \multirow{3}{*}{$\begin{array}{l}\text { III. Chloride depleted } \\
\text { using bicarbonate } \\
\mathrm{NaHCO}_{3} \text { load }\end{array}$} & 4 & \multirow{3}{*}{$\begin{array}{l}1.3 \mathrm{mM} \\
\mathrm{NaHCO}_{3} \\
2.0 \mathrm{mM} \\
\mathrm{NaHCO}_{3} \\
2.0 \mathrm{mM} \\
\mathrm{NaHCO}_{3}\end{array}$} & 1.56 & 1.42 & .36 & $.15 t$ & .51 & $7.3 \dagger$ & .82 & - & .05 & 3.49 \\
\hline & 5 & & 1.61 & 1.00 & .33 & $.09 \dagger$ & .42 & $7.3 \dagger$ & .34 & - & $<.05$ & 3.03 \\
\hline & 6 & & 1.33 & .84 & .30 & .13 & .43 & 7.3 & .32 & - & $<.05$ & 2.60 \\
\hline \multirow{3}{*}{$\begin{array}{l}\text { IV. Chloride depleted } \\
\text { using bicarbonate } \\
\text { and } \mathrm{NaH}_{2} \mathrm{PO}\end{array}$} & 4 & \multirow{3}{*}{$\begin{array}{l}1.4 \mathrm{mM} \\
\mathrm{NaH}_{2} \mathrm{PO} \\
2.0 \mathrm{mM}_{4} \\
\mathrm{NaH}_{2} \mathrm{PO}_{4} \\
2.0 \mathrm{mM} \mathrm{NaH}_{2} \mathrm{PO}\end{array}$} & .91 & 1.25 & .33 & .58 & .91 & 6.2 & 1.54 & - & $<.05$ & 3.07 \\
\hline & 5 & & .58 & .84 & .72 & .82 & 1.54 & 6.1 & 1.05 & 一 & $<.05$ & 2.96 \\
\hline & 6 & & .66 & .87 & .80 & 1.38 & 2.18 & 5.9 & 1.13 & - & $<.05$ & 3.71 \\
\hline $\begin{array}{l}\text { V. Chloride depleted } \\
\text { using nitrate }\end{array}$ & $\begin{array}{l}4 \\
5 \\
6\end{array}$ & $\begin{array}{l}\mathbf{0} \\
\mathbf{0} \\
\mathbf{0}\end{array}$ & $\begin{array}{l}.71 \\
.08 \\
.07\end{array}$ & $\begin{array}{r}1.01 \\
.34 \\
.07\end{array}$ & $\begin{array}{l}1.68 \\
1.20 \\
1.13\end{array}$ & $\begin{array}{l}.66 \\
.23 \\
.18\end{array}$ & $\begin{array}{l}2.34 \\
1.43 \\
1.31\end{array}$ & $\begin{array}{l}5.8 \\
6.5 \\
6.6\end{array}$ & $\begin{array}{l}.69 \\
.22 \\
.29\end{array}$ & $\begin{array}{r}1.89 \\
.19 \\
.04\end{array}$ & $\begin{array}{l}<.05 \\
<.05 \\
<.05\end{array}$ & $\begin{array}{l}4.06 \\
1.85 \\
1.45\end{array}$ \\
\hline
\end{tabular}

* Values expressed as mM per day. Any intake of electrolyte indicated.

$\dagger$ Certain urines in this group were alkaline with no T. A. 


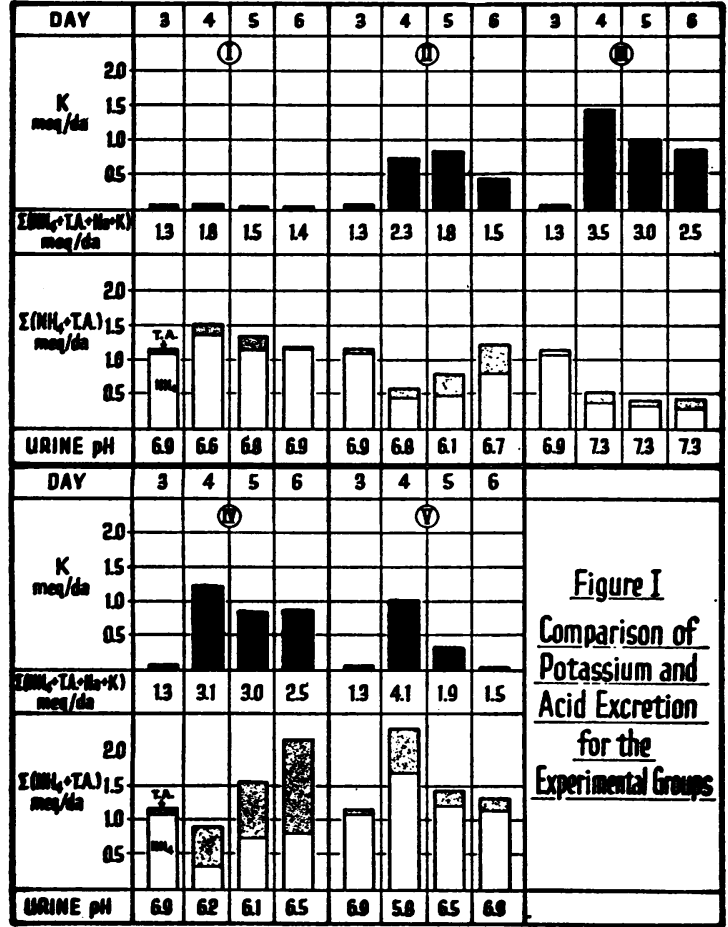

Figure 1

anion excretion is approximated by the sum of the predominant cations, sodium, potassium, ammonia, and titratable acid.

The data for the day preceding lavage, day 3, illustrate the ability of the rat to excrete urine virtually free of sodium and potassium. The anion excreted was accompanied by ammonia predominantly.

In the control Group I, in which no electrolyte was removed, the urine anion excretion on day 4 , following lavage, increased and this increase was accompanied by a comparable increase in ammonia excretion. Virtually no increase in potassium excretion occurred (Figure 1).

In Groups II-V, in which chloride was removed, an even greater increase in anion excretion occurred following lavage. However, in Groups II, III, and IV this increase was accompanied by a decrease in ammonia and total acid excretion. Reduction in ammonia excretion persisted in these three groups for the remainder of the experiment (Figure 1), even though urine $\mathrm{pH}$ in Groups II and IV was lower than it was in the control group where ammonia excretion increased.

In Group $\mathrm{V}$, in which nitrate was exchanged for chloride, over 90 per cent of the nitrate was excreted within two days. This resulted in a very large increase in anion excretion which was accompanied by a large increase in both ammonia and titratable acid excretion as well as sodium and potassium (Figure 1).

In these experiments, then, neither urine $\mathrm{pH}$, ammonia excretion, titratable acid excretion, nor the sum of the two showed a consistent response to the induced alkalosis.

Potassium excretion, on the other hand, was consistently and greatly increased in each instance. Since no potassium was given in the diet, this represented a net loss of body potassium. The excretion was greatest in the two groups given additional sodium, Groups III and IV (Table II). This was reflected in lower muscle potassium values and higher sodium values (Table III).

TABLE III

Serum and muscle data*

Averages for Each Group

\begin{tabular}{|c|c|c|c|c|c|c|c|c|c|c|c|c|}
\hline \multirow{2}{*}{$\begin{array}{l}\text { Experi- } \\
\text { mental } \\
\text { groups }\end{array}$} & \multicolumn{2}{|c|}{ Per L. serum } & \multicolumn{2}{|c|}{ Per Kg. ECW } & \multicolumn{8}{|c|}{ Per $100 \mathrm{gm}$. dry fat-free muscle } \\
\hline & {$\left[\mathrm{mM}_{2}\right]_{0}$} & $\underset{m M}{[\mathrm{~K}]}$ & $\underset{m M}{[\mathrm{Na}]_{\bullet}}$ & $\left.{ }_{m M}^{[C l}\right]_{0}$ & $\underset{\text { gm. }}{\left(\mathrm{TMW}_{\mathrm{m}}\right.}$ & $\underset{m M}{(\mathrm{Na}))_{\mathbf{m}}}$ & $\cdot{ }_{m M}^{(\mathrm{Cl})_{m}}$ & $\begin{array}{c}(\mathrm{ECW})_{\mathrm{m}} \\
\mathrm{gm} .\end{array}$ & ${ }_{m M}^{(\mathbf{K}} \mathbf{i}$ & $\underset{m M}{(\mathrm{Na})}$ & $\underset{m M}{(\mathrm{Na}+\mathrm{K})_{i}}$ & $\underset{\text { gm. }}{(\mathrm{ICW})_{\mathrm{m}}}$ \\
\hline $\begin{array}{l}\text { I } \\
\text { II } \\
\text { III } \\
\text { IV } \\
\text { V }\end{array}$ & $\begin{array}{l}24.6 \\
30.2 \\
39.3 \\
33.5 \\
32.7\end{array}$ & $\begin{array}{l}2.9 \\
2.1 \\
2.4 \\
2.3 \\
3.2\end{array}$ & $\begin{array}{l}141.2 \\
141.8 \\
143.5 \\
141.8 \\
141.8\end{array}$ & $\begin{array}{r}113.5 \\
97.9 \\
98.9 \\
98.5 \\
101.8\end{array}$ & $\begin{array}{l}319 \\
304 \\
310 \\
312 \\
310\end{array}$ & $\begin{array}{r}7.35 \\
9.13 \\
13.24 \\
11.03 \\
8.16\end{array}$ & $\begin{array}{l}4.04 \\
3.14 \\
3.30 \\
3.46 \\
3.00\end{array}$ & $\begin{array}{l}36 \\
32 \\
34 \\
35 \\
30\end{array}$ & $\begin{array}{l}39.89 \\
36.83 \\
34.45 \\
34.20 \\
37.45\end{array}$ & $\begin{array}{l}2.32 \\
4.64 \\
8.45 \\
6.06 \\
3.98\end{array}$ & $\begin{array}{l}42.2 \\
41.5 \\
42.8 \\
40.7 \\
41.5\end{array}$ & $\begin{array}{l}284 \\
270 \\
276 \\
277 \\
280\end{array}$ \\
\hline
\end{tabular}

* Abbreviations are as follows: TMW-Total Muscle Water; ECW-Extracellular Water; ICW-Intracellular Water; $m$-refers to whole muscle; $s$-refers to serum; e-refers to EC phase; $i$-refers to IC phase; Figures in () are values expressed per $100 \mathrm{gm}$. dry fat-free muscle; Figures in [ ] refer to concentration per $\mathrm{L}$. serum or water; $[\mathrm{Na}]_{\mathrm{e}} \times \frac{.96}{.94} \equiv[\mathrm{Na}]_{e} ; \frac{(\mathrm{Cl})_{\mathrm{m}}}{[\mathrm{Cl}]_{\mathrm{e}}} \equiv(\mathrm{ECW})_{\mathrm{m}} ;(\mathrm{TMW})_{\mathrm{m}}-(\mathrm{ECW})_{\mathrm{m}}=(\mathrm{ICW})_{\mathrm{m}} ;[\mathrm{Cl}]_{\mathrm{o}} \times \frac{1}{.96 \times .94}=[\mathrm{Cl}]_{\mathrm{e}} ;[\mathrm{Na}]_{0} \times$ $(\mathrm{ECW})_{\mathrm{m}}=(\mathrm{Na})_{e} ;(\mathrm{Na})_{\mathrm{m}}-(\mathrm{Na})_{\mathrm{e}}=(\mathrm{Na})_{\mathrm{i}} ;(\mathrm{K})_{\mathrm{m}}=(\mathrm{K})_{\mathrm{i}} ; .96$-Gibbs Donnan Factor: .94-gm. water per ml. serum. 
Two additional experiments were done. One group was made alkalotic by peritoneal lavage with isotonic sodium bicarbonate similar to Group II. Subsequently the animals were each given 2 $\mathrm{mM}$ per day of sodium bicarbonate and $2 \mathrm{mM}$ per day of potassium bicarbonate after the lavage (days 4,5 , and 6 ). The total excretion of potassium for this three-day period was consistently greater than the intake resulting in an average net deficit of $2.0 \mathrm{mEq}$. of body potassium. This also resulted in a lowered muscle potassium at the end of the experiments. (Muscle $\mathrm{K}: 36.2 \mathrm{mEq}$. per $100 \mathrm{gm}$. FF muscle.)

A second experiment was carried out as a control for the group in which nitrate was substituted for chloride. Animals, after being prepared on the electrolyte free diet, were given an oral load of sodium nitrate equivalent to that used in the lavage fluid. The nitrate excretion was rapid and this increased greatly the total anion excretion. However, the excretion of potassium was less than that of the control group (Group I).

It, therefore, seems clearly established that potassium excretion occurred specificially in response to some effect of chloride removal and was observed consistently in all such instances to proceed until muscle potassium concentration was decreased.

The serum and muscle data (Table III) are included to demonstrate that all the experimental groups depleted of chloride did develop alkalosis as measured by serum bicarbonate and did undergo a reduction in cell potassium and a gain in cell sodium. The greater changes in Groups III and IV have already been pointed out.

\section{DISCUSSION}

The excretion of potassium leading to a reduction in muscle potassium in response to metabolic alkalosis is predictable from previous studies (13, 14). Recently the reduction in muscle potassium has been correlated with serum $\mathrm{pH}$ rather than serum bicarbonate by Cooke, Segar, Cheek, Coville, and Darrow (15). Acute studies on potassium excretion related the rate of excretion to serum $\mathrm{pH}(16,17)$. If this be the case, then the potassium excretion observed here may be presumed to result from the elevated serum $\mathrm{pH}$ rather than the increase in either serum bicarbonate concentration or $\mathrm{pCO}_{2}$.

It is evident that potassium excretion in these experiments was not significantly influenced by the $\mathrm{pH}$ or the anion composition of urine. Providing more base as sodium and potassium bicarbonate did not prevent a net loss of potassium. Only the giving of sodium influenced the loss by increasing it.

The early drop in serum potassium reflected in the peritoneal fluid data (Table I) of the alkalotic groups over the control group was observed prior to the excretion of potassium. This suggests that the filtered potassium at this time was diminished. Glomerular filtration rates were not measured to substantiate this.

These observations suggest that the potassium excretion observed under these circumstances was achieved by the tubular exchange of potassium for sodium in response to an elevated serum $\mathrm{pH}$ or some unmeasured change within the cell related to $\mathrm{pH}$. The only other factor which appeared to affect this excretion was the ingestion of sodium which presumably led to an increased reabsorption as well as an increased excretion of sodium. If sodium reabsorption is effected through the exchange of hydrogen and potassium ions, it is possible to infer from these data that the increase in potassium excretion observed with sodium ingestion is a result of increased ion exchange within the tubule.

The data on acid excretion permit only negative conclusions. In these experiments neither ammonia nor titratable acid excretion correlated with potassium excretion. The excretion of each appeared to be related to the anions being excreted and to bear no direct relation to the state of alkalosis or to potassium excretion.

It is further evident that the state of alkalosis does not diminish the ability of the kidney to excrete acid. In Groups II and IV where serum bicarbonate was constantly elevated above control values (Table III) urine acidity and titratable acid excretion were both increased (Figure 1). In Group $\mathrm{V}$ the serum bicarbonate rose from a low of $22 \mathrm{mEq}$. per L. immediately following lavage to $32.7 \mathrm{mEq}$. per $\mathrm{L}$. at the end of the experiment. However, urine acidity, titratable acid excretion, and ammonia excretion were all above control 
values during the development of alkalosis. In Group III given added bicarbonate, the expected alkalinity of the urine was observed.

These data constitute additional evidence for the existence of a primary relationship between metabolic alkalosis and muscle potassium concentration in which alkalosis results in the urinary excretion of potassium sufficient to lower muscle concentration. The constancy of the finding suggests that the relationship is direct and that potassium excretion will proceed until a lowering of cell potassium occurs or the alkalosis is ameliorated.

There is evidence that urine $\mathrm{pH}$, ammonia, and titratable acid excretion are not directly related to alkalosis or reciprocally related to potassium excretion. Their excretion appeared to depend on a complex system of variables including anion excretion, and sodium excretion and they are only indirectly affected by the state of alkalosis.

Since no measure of sodium reabsorption was made, no inferences can be made with respect to the postulate relating hydrogen ion secretion to sodium reabsorption in the state of alkalosis and potassium secretion. The pertinence of such measurements is suggested by the observed effect of sodium ingestion, i.e., to increase the degree of alkalosis and to increase potassium excretion.

\section{SUMMARY}

1. Male rats were prepared for three days on an electrolyte-free diet and then made chloride deficient and alkalotic by peritoneal dialysis. Four groups were studied utilizing various electrolyte intakes, and these were compared to a control group similarly treated but not made alkalotic.

Urine cation excretion was observed for the day preceding dialysis and for three days subsequent to it. At the end of this period serum and muscle were obtained for analysis.

2. In contrast to the controls; all the animals made alkalotic excreted large amounts of potassium resulting in net deficits. This resulted in a lowering of cell (muscle) potassium and a gain in cell sodium.

3. Sodium ingestion increased the excretion of potassium and accentuated the muscle changes.

4. The alkalosis did not exert a consistent effect on ammonia or titratable acid excretion under the varying conditions of the experiment.

5. Evidence was cited to indicate that the potassium excretion was effected by an ion exchange system as a direct and primary response to the induced alkalosis and that the excretion resulted in cell deficit.

The varying effects on ammonia and titratable acid excretion suggested that the excretion of these ions was not directly affected by the induced alkalosis.

\section{REFERENCES}

1. Berliner, R. W., Kennedy, T. J., Jr., and Hilton, J. G., Renal mechanisms for excretion of potassium. Am. J. Physiol., 1950, 162, 348.

2. Mudge, G. H., Foulks, J., and Gilman, A., The renal excretion of potassium. Proc. Soc. Exper. Biol. \& Med., 1948, 67, 545.

3. Berliner, R. W., Kennedy, T. J., Jr., and Orloff, J., Relationship between acidification of the urine and potassium metabolism. Effect of carbonic anhydrase inhibition on potassium excretion. Am. J. Med., 1951, 11, 274.

4. Berliner, R. W., Renal secretion of potassium and hydrogen ions. Federation Proc., 1952, 11, 695.

5. Darrow, D. C., Changes in muscle composition in alkalosis. J. Clin. Invest., 1946, 25, 324.

6. Grollman, A., Turner, L. B., and MacLean, J. A., Intermittent peritoneal lavage in nephrectomized dogs and its application to the human being. Arch. Int. Med., 1951, 87, 379.

7. Wallace, W. M., Holliday, M., Cushman, M., and Elkinton, J. R., The application of the internal standard flame photometer to the analysis of biologic material. J. Lab. \& Clin. Med., 1951, 37,621 .

8. Fiske, C. H., and SubbaRow, Y., The colorimetric determination of phosphorous. J. Biol. Chem., 1925, 66, 375.

9. Van Slyke, D. D., and Hiller, A., Application of Sendroy's iodometric chloride titration to proteincontaining fluids. J. Biol. Chem., 1947, 167, 107.

10. Van Slyke, D. D., and Neill, J. M., The determination of gases in blood and other solutions by vacuum extraction and manometric measurement. I. J. Biol. Chem., 1924, 61, 523.

11. Conway, E. J., Microdiffusion analysis and volumetric error. Rev. ed., London, C. Lockwood, 1947.

12. Wilson, D. W., and Ball, E. G., A study of the estimation of chloride in blood and serum. J. Biol. Chem., 1928, 79, 221.

13. Darrow, D. C., Schwartz, R., Iannucci, J. F., and Coville, F., The relation of serum bicarbonate concentration to muscle composition. J. Clin. Invest., 1946, 27, 198. 
14. Cotlove, E., Holliday, M. A., Schwartz, R., and Wallace, W. M., Effects of electrolyte depletion and acid-base disturbance on muscle cations. Am. J. Physiol., 1951, 167, 665.

15. Cooke, R. E., Segar, W. E., Cheek, D. B., Coville, F. E., and Darrow, D. C., The extrarenal correction of alkalosis associated with potassium deficiency. J. Clin. Invest., 1952, 31, 798.
16. Singer, R. B., Clark, J. K., Barker, E. S., and Elkinton, J. R., The effects of acute respiratory alkalosis on electrolyte excretion and renal hemodynamics in man. J. Clin. Invest., 1952, 31, 663.

17. Singer, R. B., Elkinton, J. R., Barker, E. S., and Clark, J. K., Transfers of cellular cations during acute respiratory alkalosis and acidosis experimentally produced in man. J. Clin. Invest., 1953, 32, 604. 